\title{
FINANCIAL DISTRESS, LEVERAGE, PERSISTENSI LABA DAN UKURAN PERUSAHAAN TERHADAP KONSERVATISME AKUNTANSI
}

\author{
Entis Haryadi \\ Universitas Serang Raya \\ Entis_haryadi@yahoo.com \\ Titi Sumiati \\ Universitas Serang Raya \\ Titisu1209@gmail.com \\ Nana Umdiana \\ Universitas Srang Raya \\ nanaumdianaunsera@gmail.com
}

\begin{abstract}
Conservatism is a principle of prudence in the application of financial statements that are still in conflict with managers and parties related to the company. This study aims to determine the effect of financial distress, leverage, earnings persistence and company size on the accounting conservatism of chemical sub-sector manufacturing companies listed on the Indonesia Stock Exchange in the period 2014 - 2018.

This research was conducted using quantitative methods. The study population numbered 9 companies and sampled as many as 6 companies (30 financial statements) using purposive sampling. Data obtained from the Indonesian Stock Exchange Serang branch office representatives and analyzed with SPSS version 25.

Based on the results of the study it can be concluded that: 1) Financial Distress does not significantly influence accounting conservatism 2) Leverage does not significantly influence accounting conservatism 3) Profit Persistence influences significantly to accounting conservatism 4) Company size has no effect on accounting conservatism. 5) Financial Distress, Leverage, Earning Persistence and Company Size influences to accounting conservatism.
\end{abstract}

Keywords: conservatism, financial distress, leverage, earnings persistence, company size. 


\section{PENDAHULUAN}

Manajemen laba seperti yang terjadi pada PT. Kimia Farma pada tahun buku 2011 yaitu adanya tindakan penggelembungan (mark up) laba bersih menjadi kabar buruk dan merugikan bagi investor, kreditor dan pihak-pihak yang berkepentingan lainnya (Rahmawati dalam Brilianti, 2013). Kasus seperti itu menunjukkan perlunya informasi keuangan yang berkualitas dan bermanfaat bagi para penggunanya. Dalam mengolah akuntansi agar dapat menghasilkan informasi yang berkualitas dan bermanfaat maka perusahaan dihadapkan pada keterbatasan (constraint) salah satunya adalah konservatisme.

Penerapan prinsip konservatisme ini dapat menghasilkan angka-angka laba yang rendah dan angka-angka biaya yang tinggi. Hal ini dikarenakan prinsip tersebut memperlambat pengakuan pendapatan, tetapi biaya yang terjadi lebih cepat diakui. Akibatnya, laba yang ada dalam laporan keuangan cenderung understatement atau terlalu rendah dalam periode sekarang dan overstatement terhadap laba pada periode-periode berikutnya. Lebih lanjut, laba tersebut dapat dikatakan fluktuatif, di mana laba yang berfluktuatif akan mengurangi daya prediksi laba untuk memprediksi aliran kas perusahaan pada masa yang akan datang (Sari dan Adhariani 2009).

Banyak pertentangan yang terjadi mengenai pemakaian prinsip konservatisme dalam penyajian laporan keuangan. Mayangsari dan Wilopo dalam Noviantari dan Dwi Ratnadi (2015) juga menyatakan bahwa konsep konservatisme ini merupakan konsep yang kontroversial. Pihak yang menentang berpendapat bahwa prinsip tersebut dianggap sebagai kendala dalam mempengaruhi kualitas laporan keuangan, yaitu tidak tercapainya tujuan pengungkapan secara penuh semua informasi yang relevan. Para peneliti yang menentang menganggap bahwa laba yang dihasilkan dari prinsip ini tidak berkualitas, tidak relevan dan tidak bermanfaat.

Di lain pihak, konservatisme dalam akuntansi bermanfaat untuk menghindari perilaku oportunistik manajer berkaitan dengan kontrak-kontrak yang menggunakan laporan keuangan sebagai media kontrak (Watts, 2003). Ketika kepemilikan manajer rendah, maka manajer cenderung untuk melakukan tindakan oportunistik seperti manajemen laba agar laba yang dilaporkan menjadi besar, sehingga kinerjanya dinilai lebih baik oleh pemegang saham dan imbalan yang akan diterima besar (Lafond, 2007). Lebih lanjut, pihak yang mendukung adanya pemakaian prinsip ini juga menginginkan agar perusahaan tidak berlebihan dalam melaporkan hasil usahanya, sehingga para kreditor dan investor sebagai pihak eksternal yang menggunakan laporan keuangan tidak tertipu pada angka-angka aset yang terlihat tinggi. Selain itu, agar laporan keuangan tidak menyesatkan pengguna dalam mengambil keputusan.

Financial distress terjadi apabila perusahaan tidak dapat memenuhi kewajiban pembayarannya kepada pihak kreditor (Brigham dan Daves, 2003). Financial distress bisa diartikan sebagai munculnya sinyal atau gejala-gejala awal kebangkrutan terhadap penurunan kondisi keuangan yang dialami oleh suatu perusahaan atau juga kondisi yang terjadi sebelum terjadinya kebangkrutan ataupun likuidasi. Manajer mengatur tingkat konservatisme akuntansi pada saat perusahaan mengalami kondisi kesulitan keuangan (Pramudita, 2012). Bagi pengguna laporan keuangan perlu dipahami bahwa perubahan laba akuntansi selain dipengaruhi oleh kinerja manajer juga dapat dipengaruhi dari kebijakan konservatisme akuntansi yang ditempuh oleh manajer. Financial distress dapat 
mendorong pemegang saham untuk mengganti manajer perusahaan karena manajer dianggap tidak mampu mengelola perusahaan dengan baik. Hal tersebut akan mendorong manajer untuk mengubah laba yang menjadi tolak ukur kinerja manajer dengan jalan mengatur tingkat konservatisme akuntansi. Apabila suatu perusahaan tidak memiliki masalah keuangan, manajer tidak akan menghadapi tekanan pelanggaran kontrak.

Leverage menunjukkan seberapa besar aset perusahaan dibiayai oleh hutang dan merupakan indikasi tingkat keamanan dari para pemberi pinjaman. Lo (2006) menyatakan jika perusahaan mempunyai hutang yang tinggi, maka kreditor juga mempunyai hak untuk mengetahui dan mengawasi jalannya kegiatan operasional perusahaan. Oleh karena itu, kreditor akan meminta perusahaan untuk menerapkan prinsip kehati-hatian dalam pelaporan laba, sehingga kreditor yakin akan keamanan dan pengembalian dananya. Dalam penelitiannya, Erwin Saputra (2016) menyatakan bahwa semakin tinggi leverage yang dimiliki oleh perusahaan, maka kreditur mempunyai hak lebih besar dalam mengawasi dan mengetahui penyelenggaraan operasi dan akuntansi perusahaan karena kreditur berkepentingan terhadap keamanan dananya yang diharapkan dapat menguntungkan bagi dirinya. Kreditur akan cenderung menuntut manajer untuk menerapkan konservatisme dalam menyusun laporan keuangan, namun di sisi lain masih ada perusahaan yang melaporkan laporan keuangan secara berlebihan untuk menarik kreditor dalam memberikan pinjaman kepada perusahaan, sehingga perusahaan cenderung mengurangi tingkat konservatisme akuntansi dalam pelaporan keuangan.

Laba yang dihasilkan dari laporan keuangan konservatif dapat mencerminkan laba yang berkelanjutan di masa yang akan datang. Persistensi laba merupakan salah satu komponen nilai prediktif laba yang diimplikasikan melalui laba tahun berjalan yang dihubungkan dengan perubahan harga saham. Besarnya nilai revisi inilah yang menunjukkan tingkat persistensi laba. Semakin tinggi persistensi laba maka laba semakin informatif dan koefisien respon laba semakin tinggi. Hal ini dapat menunjukkan bahwa perusahaan dapat mempertahankan laba dari waktu ke waktu. Laba yang persisten merupakan good news bagi calon investor dan investor.

Lo (2006) menyatakan bahwa perusahaan yang berukuran besar cenderung akan melaporkan laba yang lebih rendah secara relatif permanen dengan menyelenggarakan akuntansi yang konservatif. Hal ini dikarenakan bahwa perusahaan yang besar cenderung akan lebih disoroti pemerintah. Pemerintah akan meminta pelayanan publik dan tanggung jawab sosial yang lebih besar pula kepada perusahaan yang labanya tinggi. Alasan lain perusahaan besar menerapkan konservatisme adalah beban pajak yang tinggi dari laba yang ditimbulkannya.

\section{LANDASAN TEORI}

Penelitian ini didasari oleh teori akuntansi positif. Belkaoui (2007) menyatakan teori positif didasarkan kepada adanya dalil bahwa manajer, pemegang saham dan aparat pengatur/politisi adalah rasional dan bahwa mereka berusaha untuk memaksimalkan kegunaan mereka yang secara langsung berhubungan dengan kompensasi dan kesejahteraan mereka. Sebenarnya ide utama dari pendekatan positif adalah untuk mengembangkan hipotesis atas faktor-faktor yang memengaruhi dunia praktik akuntansi dan untuk menguji validitas dari hipotesis ini secara empiris :

1. Untuk meningkatkan keandalan dari peramalan berdasarkan atas pengamatan 
perataan serangkaian angka akuntansi sejalan dengan suatu kecenderungan yang dianggap terbaik atau normal oleh manajemen.

2. Untuk menurunkan tingkat ketidakpastian yang dihasilkan dari fluktuasi angka pendapatan secara umum dan penurunan risiko sistematis khususnya dengan menurunkan kovarian pengembalian perusahaan dengan pengembalian pasar.

Watts dan Zimmerman mengungkapkan teori ini juga menjelaskan mengapa kebijakan akuntansi menjadi suatu masalah bagi perusahaan dan pihakpihak yang berkepentingan dengan laporan dan untuk memprediksi kebijakan akuntansi yang hendak dipilih oleh perusahaan dalam kondisi tertentu. Watts dan Zimmerman (1986) menjelaskan tiga hipotesis yang diaplikasikan untuk melakukan prediksi dalam positive accounting theory mengenai keputusan manajemen untuk bertindak konservatif atau tidak. Hipotesis-hipotesis tersebut antara lain:

$\begin{array}{crr}\text { Debt } & \text { covenant } & \text { hypothesis } \\ \text { memprediksi } & \text { bahwa } & \text { manajer }\end{array}$ meningkatkan laba dan aset untuk mengurangi biaya renegosiasi kontrak hutang ketika perusahaan memutuskan perjanjian hutangnya. Dalam debt covenant hypothesis, tingkat konservatisme dalam pelaporan laba akan berkurang karena manajer cenderung akan menaikkan laba agar memperoleh potencial loan dari kreditor. Tingkat konservatisme dalam pelaporan laba berdasarkan debt covenant hypothesis dapat dijelaskan dengan debt/equity hypothesis yang merupakan pembatasan dari debt covenant (Sari dan Ardhani, 2009).

Debt covenant hypothesis ini dapat dijelaskan dengan rasio leverage yang merupakan rasio antara total hutang dan total aset. Apabila manajemen melakukan manajemen laba ketika melakukan perjanjian hutang, maka laba cenderung tidak konservatif sehingga tingginya rasio leverage akan berbanding terbalik dengan tingkat konservatisme akuntansi. Hal tersebut dikarenakan semakin tinggi jumlah hutang yang ingin diperoleh perusahaan, maka perusahaan berupaya untuk menunjukkan kinerja yang baik agar kreditur yakin bahwa perusahaan mampu melunasi hutang-hutangnya.

Political cost hypothesis, dalam hipotesis ini perusahaan besar diprediksi lebih sensitif terhadap adanya biaya politik daripada perusahaan kecil (Watts dan Zimmerman, 1990). Biaya politik timbul akibat adanya konflik kepentingan antara manajer dengan pemerintah. Kebijakan pemerintah untuk hal tersebut adalah kewajiban membayar pajak. Semakin besar tingkat pendapatan atau laba yang diperoleh perusahaan, maka semakin besar pula pajak yang harus dibayar. Oleh karena itu untuk menghindari pembayaran pajak yang tinggi, manajemen akan cenderung melaporkan laba yang rendah sehingga terjadi pelaporan laba yang tidak konservatif.

Plan bonus hypothesis, hipotesis ini berkaitan dengan tindakan manajemen dalam memilih metode akuntansi untuk memaksimalkan laba demi mendapatkan bonus yang tinggi. Manajer sering kali berperilaku seiring dengan bonus yang diberikan. Oleh karena itu, manajemen cenderung melakukan manajemen laba agar target laba terpenuhi. Tindakan manajemen laba tersebut membuat pelaporan laba cenderung optimis dan tidak konservatif.

Kerangka pemikiran teoritis:

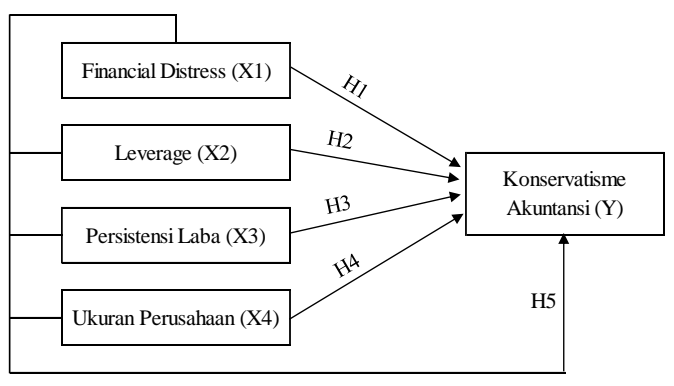


Hipotesis:

H1 : Financial Distress berpengaruh signifikan terhadap konservatisme akuntansi.

$\mathrm{H} 2$ : Leverage berpengaruh signifikan terhadap konservatisme akuntansi.

H3 : Persistensi laba berpengaruh signifikan terhadap konservatisme akuntansi.

H4 : Ukuran perusahaan berpengaruh signifikan terhadap konservatisme akuntansi.

H5 : Financial Distress, Leverage, Persistensi Laba dan Ukuran perusahaan berpengaruh signifikan terhadap konservatisme akuntansi.

\section{METODE PENELITIAN}

Penelitian ini merupakan penelitian deskriptif kuantitatif, data yang diperoleh dari sampel populasi penelitian dianalisis sesuai dengan metode statistik yang digunakan kemudian diinterpretasikan.

Di dalam penelitian ini yang menjadi populasi penelitian adalah perusahaan manufaktur yang terdaftar di Bursa Efek Indonesia pada sektor Industri Dasar dan Kimia pada sub sektor kimia selama tahun 2014 - 2018. Populasi dalam penelitian ini adalah sebanyak 45 populasi laporan keuangan dari total 9 perusahaan selama 5 periode.

Metode yang digunakan dalam pemilihan sampel penelitian ini menggunakan metode purposive sampling. Diperoleh sebanyak 30 sampel laporan keuangan.

\section{Definisi Operasional Variabel}

\section{Variabel Dependen}

Variabel dependen dalam penelitian ini adalah konservatisme akuntansi. Pengukuran variabel dependen menggunakan market to book ratio yaitu dengan membandingkan total hutang dengan harga penutupan saham per lembar yang dikalikan nilai buku saham per lembar (Faradillah. 2010).

$$
\text { CON_MKT }=\frac{\text { Total Equity }}{\text { Closing Price } x \text { Issued Shares }}
$$

(Sumber : Reskino dan Vemiliyarni 2014)

\section{Variabel Independen}

Financial Distress merupakan variabel independen pertama dalam penelitian ini diukur dengan menggunakan model Altman yaitu perhitungan Z Score sebagai berikut:

$\mathrm{Zi}: 0,717 \mathrm{X}_{1}+0,847 \mathrm{X}_{2}+3,107 \mathrm{X}_{3}+$ $0,42 \mathrm{X}_{4}+0,998 \mathrm{X}_{5}$

Dimana :

X1 = (Aktiva Lancar - Utang Lancar $)$ / Total Aktiva

$\mathrm{X} 2$ = Laba ditahan / Total Aset

X3 = Laba Sebelum Bunga dan Pajak / Total Aset

X4 = Nilai Buku Saham Biasa dan Preferen / Nilai Buku Total Utang X5 = Penjualan $/$ Total Aset

(Sumber : Hanafi \& Halim, 2016)

Leverage merupakan variabel independen kedua dalam penelitian ini dukur dengan cara membandingkan nilai hutang dengan nilai asset yang dimiliki perusahaan.

$$
\text { Leverage }=\frac{\text { Total Debt }}{\text { Total Assets }}
$$

(Sumber : Hanafi \& Halim, 2016)

Persistensi laba merupakan variabel independen ketiga dalam penelitian ini diukur dengan cara membandingkan laba sebelum pajak dibagi dengan rata-rata total asset perusahaan.

Persistensi Laba $=\frac{\text { Earning Before Tax }}{\text { Rata }- \text { rata Total Aset }}$

(Sumber : Hanlon, 2005) 
Ukuran perusahaan merupakan variabel independen keempat dalam penelitian ini dikukur dengan menghitung logaritma natural dari total asset yang dimiliki perusahaan.

$$
\text { Size }=\ln (\text { Total Aset })
$$

(Sumber : Dini Firmasari, 2016)

\section{HASIL DAN PEMBAHASAN}

\section{Statistik Deskriptif}

Pada tabel berikut diketahui bahwa financial distress memiliki nilai minimum 1,0194 dan maksimum 4,9820. Standar deviasi yang lebih kecil dari nilai rata-rata menunjukkan bahwa variabel financial distress tidak berbeda antara satu perusahaan dengan perusahaan lainnya.

Leverage memiliki nilai minimum 0,0767 dan maksimum 0,6616. Standar deviasi yang lebih kecil dari nilai rata-rata menunjukkan bahwa variabel leverage tidak berbeda antara satu perusahaan dengan perusahaan lainnya.

Persistensi laba memiliki nilai minimum 0,0024 dan maksimum 0,1881.

Standar deviasi yang lebih kecil dari nilai rata-rata menunjukkan bahwa variabel persistensi laba tidak berbeda antara satu perusahaan dengan perusahaan lainnya.

Ukuran perusahaan memiliki nilai minimum dari ukuran perusahaan 25,7188 dan maksimum 31,4537. Standar deviasi yang lebih kecil dari nilai rata-rata menunjukkan bahwa variabel ukuran perusahaan tidak berbeda antara satu perusahaan dengan perusahaan lainnya.

Konservatisme akuntansi memiliki nilai minimum dari konservatisme akuntansi 0,2175 dan maksimum 4,4415. Standar deviasi yang lebih kecil dari nilai rata-rata menunjukkan bahwa variabel konservatisme akuntansi tidak berbeda antara satu perusahaan dengan perusahaan lainnya.

\begin{tabular}{|c|c|c|c|c|}
\hline \multicolumn{5}{|c|}{ Descriptive Statistics } \\
\hline & Minimum & Maximum & Mean & $\begin{array}{c}\text { Std. } \\
\text { Deviation }\end{array}$ \\
\hline Fis?:24: & 1.0194 & 4.9820 & 2.115083 & 0.8667128 \\
\hline Eever & 0767 & 0.6616 & 0.321130 & 0.1978810 \\
\hline Fysisistai & 0.0024 & 0.1881 & 0.074557 & 0.0494364 \\
\hline S!:표 & 25.7188 & 31.4537 & 27.779683 & 1.7319074 \\
\hline 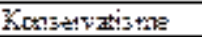 & 0.2175 & 4.4415 & 1.924297 & 1.1247307 \\
\hline Pa:L & & & & \\
\hline
\end{tabular}

\section{Uji Asumsi Klasik}

\section{Uji Normalistas}

\begin{tabular}{|c|c|c|}
\hline \multicolumn{3}{|c|}{ One-Sample Kolmogorov-Smirmov T est } \\
\hline & & $\begin{array}{c}\text { Unstandardized } \\
\text { Residual }\end{array}$ \\
\hline \multicolumn{2}{|l|}{ Xi } & 30 \\
\hline \multirow{2}{*}{ 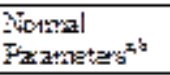 } & Ks:an & .0000000 \\
\hline & 8년.Dexiżia: & .89275681 \\
\hline \multirow{3}{*}{$\begin{array}{l}\text { Pkst Exwerene } \\
\text { Bifferences }\end{array}$} & Ábaolike & .105 \\
\hline & Ycritive & .105 \\
\hline & Pegasize & -.069 \\
\hline \multicolumn{2}{|l|}{ Fotstzistic } & .105 \\
\hline \multicolumn{2}{|c|}{ 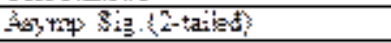 } & $.200^{\text {fd }}$ \\
\hline
\end{tabular}

Berdasarkan hasil uji normalitas pada tabel di atas, dapat disimpulkan bahwa nilai kolmogrov-smirnov adalah 0,105 dengan probabilitas signifikansi sebesar 0,200. Hal ini menunjukkan berarti nilai sig $0,200>0,05$ sehingga dapat disimpulkan bahwa data residual telah terdistribusi dengan normal.

\section{Uji Multikolinearitas}

\begin{tabular}{|c|c|c|c|}
\hline \multirow{2}{*}{\multicolumn{2}{|c|}{ Model }} & \multicolumn{2}{|c|}{ Collinearity Statistics } \\
\hline & & \multirow{2}{*}{ Tolerance } & \multirow{2}{*}{ VIF } \\
\hline$\xi$ & $\langle$ Cotastand $\rangle$ & & \\
\hline & Einenxial Sistress & .403 & 2.480 \\
\hline & Eeverace & 323 & 3.098 \\
\hline & Peraiateris & .777 & 1.287 \\
\hline & Sire & 386 & 2.592 \\
\hline
\end{tabular}

Berdasarkan hasil dari uji pada table berikut, dapat disimpulkan bahwa financial distress, leverage, persistensi laba dan ukuran perusahaan memiliki nilai variance inflantion factor (VIF) tidak lebih dari 10 serta nilai tolerance memiliki nilai di atas $10 \%$ atau di atas 0,10. Dari hasil uji 
tersebut dapat disimpulkan bahwa tidak ada multikolinearitas antar variabel

independen dalam model regresi pada penelitian ini.

\section{Uji Heteroskedastisitas}

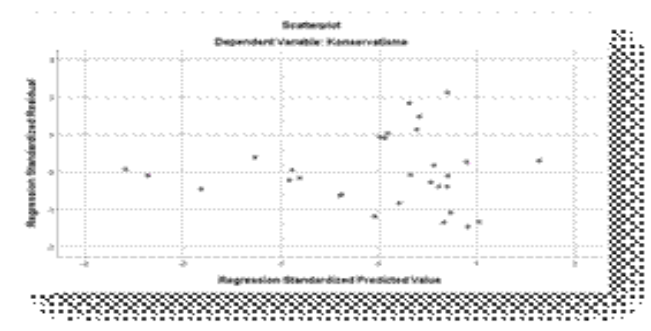

Berdasarkan hasil dari uji heteroskedastisitas dengan melihat pola gambar scatterplot, maka dapat disimpulkan bahwa uji heteroskedastisitas terpenuhi.

\section{Uji Autokorelasi}

\begin{tabular}{|c|c|}
\hline \multicolumn{2}{|c|}{ Runs T est } \\
\hline & Unstandardized Residual \\
\hline Tosi Yalue" & .02429 \\
\hline Casem < Sest tislese & 15 \\
\hline Kased $>=$ Eest +2 tye & 15 \\
\hline Totat Cases & 30 \\
\hline Virmber at Rer:s & 11 \\
\hline $\bar{I}$ & -1.672 \\
\hline 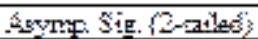 & .094 \\
\hline
\end{tabular}

Berdasarkan tabel diatas dapat diketahu nilai test adalah 0,02429 dengan probabilitas $0,094>0,05$ yang berarti bahwa residual random sehingga dapat disimpulkan tidak terjadinya autokorelasi, dengan demikian asumsi autokorelasi terpenuhi.

\section{Analisis Regresi Linier Berganda}

\begin{tabular}{|c|c|c|c|c|}
\hline & & \multicolumn{2}{|c|}{$\begin{array}{c}\text { Unstandardized } \\
\text { Coefficients }\end{array}$} & $\begin{array}{c}\text { Standardized } \\
\text { Coefficients }\end{array}$ \\
\hline \multicolumn{2}{|c|}{ Model } & B & Std. Error & Beta \\
\hline \multirow[t]{5}{*}{1} & (Constant) & 10.577 & 4.512 & \\
\hline & $\begin{array}{l}\text { Financial } \\
\text { Distress }\end{array}$ & .310 & .324 & .239 \\
\hline & Leverage & 1.776 & 1.588 & .312 \\
\hline & Persistensi & 7.871 & 4.097 & .346 \\
\hline & Size & -.334 & .166 & -.515 \\
\hline
\end{tabular}

Berdasarkan data yang ada pada tabel di atas, maka persamaan regresi dapat dijabarkan sebagai berikut :

$\mathrm{Y}=10,577+0,310 \mathrm{FD}+1,776$ Lev + 7,871Persistensi - 0,334Size

\section{Uji Koefisien Determinasi}

\begin{tabular}{|l|c|r|r|}
\hline Model & R & R Square & Adjusted R Square \\
\hline 1 & $.608^{\mathrm{a}}$ & .370 & .269 \\
\hline
\end{tabular}

Berdasarkan hasil uji koefisien determinasi pada tabel 4.6 di atas, diketahui bahwa Adjust R Square sebesar 0,269 yang mengandung arti bahwa bernilai $26,9 \%$ nilai konservatisme dipengaruhi oleh financial distress, leverage, persistensi laba dan ukuran perusahaan, sedangkan sisanya sebanyak $73,1 \%$ lainnya dijelaskan oleh variabel lain di luar model.

\section{Uji t}

\begin{tabular}{|c|c|c|}
\hline Model & $t$ & Sig. \\
\hline Firarcisil Systreata & 954 & 349 \\
\hline Estrerset & 1.118 & .274 \\
\hline Fustasis & 3.496 & .002 \\
\hline Sizx & -2.015 & .055 \\
\hline
\end{tabular}

Berdasarkan hasil analisis uji $\mathrm{t}$ pada tabel dapat dijelaskan bahwa nilai $t_{\text {tabel }}$ dengan tingkat signifikansi $\alpha=0,05$ dengan degree of freedom $(\mathrm{df})=30-5=25$ adalah 2,060. dari hasil uji $t$ dapat dilakukan pembahasan hipotesis yang diajukan sebagai berikut :

Berdasarkan tabel di atas diketahui bahwa nilai t hitung sebesar 0,954 dengan probabilitas (sig) 0,349 . Nilai $t_{\text {hitung }}<t_{\text {tabel }}$ $(0,954<2,060)$ dan nilai probabilitas (sig) lebih besar dari nilai $\alpha(0,349>0,05)$. Dengan demikian secara parsial financial distress tidak berpengaruh secara signifikan terhadap konservatisme akuntansi. Sehingga hipotesis pertama $\left(\mathrm{H}_{1}\right)$ ditolak.

Berdasarkan tabel di atas diketahui bahwa nilai $\mathrm{t}$ hitung sebesar 1,118 dengan probabilitas ( $\mathrm{sig}) 0,274$. Nilai thitung $<\mathrm{t}_{\text {tabel }}$ $(1,118<2,060)$ dan nilai probabilitas $(\mathrm{sig})$ 
lebih besar dari nilai $\alpha(0,274>0,05)$. Dengan demikian secara parsial leverage tidak berpengaruh secara signifikan terhadap konservatisme akuntansi. Sehingga hipotesis kedua $\left(\mathrm{H}_{2}\right)$ ditolak.

Berdasarkan tabel di atas diketahui bahwa nilai t hitung sebesar 3,496 dengan probabilitas (sig) 0,002 . Nilai $t_{\text {hitung }}>t_{\text {tabel }}$ $(3,496>2,060)$ dan nilai probabilitas (sig) lebih kecil dari nilai $\alpha(0,002<0,05)$. Dengan demikian secara parsial persistensi laba berpengaruh secara signifikan terhadap konservatisme akuntansi. Sehingga hipotesis ketiga $\left(\mathrm{H}_{3}\right)$ diterima.

Berdasarkan tabel di atas diketahui bahwa nilai t hitung sebesar -2,015 dengan probabilitas (sig) 0,55 . Nilai $t_{\text {hitung }}<t_{\text {tabel }}(-$ $2,015<2,060)$ dan nilai probabilitas (sig) lebih besar dari nilai $\alpha(0,55>0,05)$. Dengan demikian secara parsial ukuran perusahaan tidak berpengaruh secara signifikan terhadap konservatisme akuntansi. Sehingga hipotesis keempat $\left(\mathrm{H}_{4}\right)$ ditolak.

\section{Uji F (Simultan)}

\begin{tabular}{|l|l|c|c|}
\hline \multicolumn{2}{|l|}{ Model } & F & Sig \\
\hline \multirow{4}{*}{1} & Regression & 3.670 & $.017^{\mathrm{b}}$ \\
\cline { 2 - 4 } & Residual & & \\
\cline { 2 - 4 } & Total & & \\
\hline
\end{tabular}

Dari tabel di atas dapat dilihat bahwa nilai signifikansi $0,017<0,05$. Hal ini berarti nilai signifikansi yang lebih kecil dari 0,05 maka model regresi yang digunakan sudah layak, sehingga dapat digunakan untuk memprediksi variabelvariabel penelitian. Dengan demikian dapat disimpulkan bahwa financial distress, leverage, persistensi laba dan ukuran perusahaan berpengaruh signifikan secara bersama-sama terhadap konservatisme akuntansi.

\section{PEMBAHASAN}

Pengaruh Financial Distress Terhadap Konservatisme Akuntansi

Berdasarkan hasil pengujian regresi menunjukkan bahwa financial distress tidak berpengaruh signifikan teradap konservatisme akuntansi. Tanda koefisien regresi variabel financial distress positif menunjukkan bahwa semakin tinggi financial distress maka tidak mempengaruhi penerapan konservatisme akuntansi dalam perusahaan. Hasil penelitian ini sejalan dengan penelitian yang dilakukan oleh Gutika Putri (2018) yang menyatakan tidak ada pengaruh antara financial distress dengan konservatisme akuntansi. Namun hasil penelitian ini tidak sejalan dengan penelitian yang dilakukan oleh Viola dan Patricia (2016) yang menyatakan adanya pengaruh secara signifikan antara financial distress dengan konservatisme akuntansi. Dalam teori akuntansi positif menyatakan bahwa manajer akan menyajikan laba perusahaan dalam jumlah yang tinggi pada saat mengalami kondisi kesulitan keuangan karena untuk mendapatkan potencial loan dari kreditor.

Financial distress mengakibatkan perusahaan membutuhkan dana lebih untuk membiayai kegiatan perusahaannya serta dana untuk membayar utangnya sehingga akan mengakibatkan tingkat utang menjadi lebih tinggi. Jika perusahaan mengalami financial distress dan tetap menggunakan akuntansi konservatif maka laporan keuangan menjadi understatement sehingga akan memberikan sinyal buruk bagi pihak eksternal terutama pihak kreditur sehingga pihak kreditur tidak akan memberikan pinjaman untuk kelangsungan usaha perusahaan sehingga ketika perusahaan sedang mengalami financial distress maka perusahaan tidak akan menerapkan prinsip konservatisme dalam penyusunan laporan keuangan. 


\section{Pengaruh Leverage \\ Konservatisme Akuntansi}

Berdasarkan hasil pengujian regresi menunjukkan bahwa leverage tidak berpengaruh signifikan terhadap konservatisme akuntansi. Tanda koefisien regresi variabel leverage positif menunjukkan bahwa semakin tinggi leverage maka tidak mempengaruhi penerapan konservatisme akuntansi. Hasil penelitian ini sejalan dengan penelitian yang dilakukan oleh Brilianti (2013) serta Maharani dan Kristanti (2019) yang menyatakan bahwa tidak ada pengaruh antara leverage dengan konservatisme akuntansi. Namun hasil penelitian ini tidak sejalan dengan penelitian yang dilakukan oleh Dewi dan Suryanawa (2014) serta Viola dan Patricia (2016) yang menyatakan adanya pengaruh positif dan pengaruh secara signifikan antara leverage dengan konservatisme akuntansi. Dalam teori akuntansi positif yang menghasilkan debt covenant hypothesis, menyatakan bahwa tingkat konservatisme dalam pelaporan laba akan berkurang bahkan cenderung tidak konservatif pada saat perusahaan memiliki hutang yang tinggi untuk mengurangi biaya renegosiasi kontrak hutang ketika perusahaan memutuskan perjanjian hutangnya.

Reskino dan Vemiliyarni (2014) mengungkapkan bahwa kemungkinan tidak berpengaruhnya leverage terhadap konservatisme akuntansi adalah karena perusahaan menerapkan sikap kehatihatian dalam keadaan yang tidak pasti, tidak peduli apakah perusahaan tersebut mengalami tingkat hutang yang tinggi atau rendah. Hal Ini dilakukan perusahaan untuk meningkatkan kepercayaan para kreditur dalam memberikan pinjamannya. Oleh karena itu perusahaan tidak menerpakan prinsip konservatisme dalam penyusunan laporan keuangannnya.

\section{Pengaruh Persistensi Laba Terhadap Konservatisme Akuntansi}

Berdasarkan hasil pengujian regresi menunjukkan bahwa persistensi laba berpengaruh signifikan terhadap konservatisme akuntansi. Tanda koefisien regresi variabel persistensi laba positif menunjukkan bahwa semakin tinggi persistensi laba maka semakin tinggi penerapan konservatisme akuntansi. Hasil penelitian ini tidak sejalan dengan penelitian yang dilakukan oleh Afifuddin (2018) yang menyatakan persistensi laba tidak berpengaruh terhadap konservatisme akuntansi.

Manajer biasanya mengakui pendapatan setelah diterima dan tidak akan mengakui pendapatan sebelum diterima agar laba yang diakuinya lebih persisten (paek, et al 2007). Di sisi lain, ketika perusahaan yang menyajikan laba tahun berjalan dengan nilai yang konservatif, maka akan lebih memudahkan manajer dalam pencapaian laba di masa yang akan datang. Sehingga peristensi laba mempengaruhi dalam pemilihan manajer perusahaan untuk menggunakan akuntansi konservatif. Dengan demikian persistensi laba menunjukkan pengaruh positif terhadap konservatisme akuntansi.

\section{Pengaruh Ukuran Perusahaan Terhadap Konservatisme Akuntansi}

Berdasarkan hasil pengujian regresi menunjukkan bahwa ukuran perusahaan tidak berpengaruh terhadap konservatisme akuntansi. Tanda koefisien regresi variabel ukuran perusahaan negatif menunjukkan bahwa semakin rendah ukuran perusahaan maka tidak mempengaruhi penerapan konservatisme akuntansi. Hasil penelitian ini sejalan dengan Rohadi (2018) serta Maharani dan Kristanti (2019) yang menyatakan bahwa ukuran perusahaan tidak berpengaruh signifikan terhadap konservatisme akuntansi. Namun hasil penelitian ini tidak sejalan dengan 
penelitian yang dilakukan oleh Noviantari dan Ratnadi (2015) yang menyatakan bahwa ukuran perusahaan berpengaruh terhadap konservatisme akuntansi. Political cost hypothesis yang dihasilkan dari teori akuntansi positif menyatakan perusahaan besar diprediksi lebih sensitif terhadap adanya biaya politik daripada perusahaan kecil, biaya politik tersebut muncul dikarenakan adanya kebijakan pemerintah dan adanya tuntutan tanggung jawab kepada masyarakat sekitar. Namun saat ini program CSR sudah menjadi budaya bagi setiap perusahaan untuk meningkatkan citra perusahaan baik perusahaan besar maupun perusahaan kecil.

Berdasarkan hasil analisis statistik, terlihat bahwa ukuran perusahaan yang diproksikan dengan logaritma natural total aset memiliki jumlah aset yang beragam. Terdapat kemungkinan bahwa peraturanperaturan yang dikeluarkan pemerintah sudah sesuai dengan apa yang diinginkan oleh perusahaan, sehingga peraturan pemerintah bukan alasan bagi para perusahaan untuk menerapkan prinsip konservatisme akuntansi. Sebagai contoh pada tahun 2008 pemerintah mengenakan tarif proporsional untuk pengenaan $\mathrm{PPh}$ badan yaitu $10 \%$ hingga $30 \%$. Pada tahun 2009, pemerintah mengenakan tarif tunggal sebesar $28 \%$ dan tahun 2010 tarif menurun menjadi $25 \%$. Tarif pajak yang semakin rendah dapat menjadi salah satu alasan bahwa pemerintah telah berusaha untuk tidak memberatkan perusahaan. Selain itu, kemungkinan perusahaan tidak menerapkan akuntansi yang konservatif adalah dikarenakan perusahaan besar cenderung ingin memperlihatkan hasil kinerja yang baik sehingga para manajer dipandang memiliki kinerja yang baik dan dapat mempengaruhi bonus para manajer.

\section{KESIMPULAN}

Berdasarkan data yang diperoleh dan dari hasil analisis data yang dilakukan maka diperoleh beberapa kesimpulan sebagai berikut :

1. Financial distress tidak berpengaruh terhadap konservatisme akuntansi. Hal ini terjadi karena kemungkinan apabila perusahaan yang mengalami financial distress namun tetap menggunakan akuntansi konservatif, maka laporan keuangan menjadi understatement sehingga akan memberikan sinyal buruk bagi pihak eksternal terutama pihak kreditur sehingga pihak kreditur tidak akan memberikan pinjaman untuk kelangsungan usaha perusahaan

2. Leverage tidak berpengaruh terhadap konservatisme akuntansi. Hal ini terjadi karena kemungkinan disebabkan prinsip konservatisme yang merupakan sikap kehati-hatian dalam menghadapi lingkungan yang tidak pasti, maka perusahaan akan selalu menerapkan prinsip ini tidak peduli apakah hutangnya tinggi atau rendah.

3. Persistensi laba berpengaruh terhadap konservatisme akuntansi. Hal ini terjadi karena semakin tinggi persistensi laba dalam suatu perusahaan maka mempengaruhi penerapan konservatisme akuntansi. Dengan diterapkannya akuntansi yang konservatif, maka laba yang dihasilkan tahun berjalan akan semakin rendah, dengan begitu pencapaian atau prediksi laba di tahun yang akan datang akan semakin mudah terealisasikan dan laba tahun ini akan mudah dijadikan standar untuk pencapaian laba di masa yang akan datang. Sehingga peristensi laba mempengaruhi dalam pemilihan manajer perusahaan untuk menggunakan akuntansi konservatif.

4. Ukuran perusahaan tidak berpengaruh terhadap konservatisme akuntansi. Hal ini terjadi karena kemungkinan peraturan-peraturan yang dikeluarkan pemerintah sudah sesuai dengan apa yang diinginkan perusahaan, sehingga peraturan pemerintah bukan merupakan 
alasan perusahaan untuk menerapkan konservatisme akuntansi.

5. Financial distress, leverage, persistensi laba dan ukuran perusahaan berpengaruh terhadap konservatisme akuntansi. Hal ini terjadi karena salah satu variabel dari penelitian ini yaitu persistensi laba berpengaruh terhadap nilai konservatisme akuntansi perusahaan, sehingga hasil uji simultan menunjukkan pengaruh yang signifikan dari keempat variabel tersebut.

\section{DAFTAR PUSTAKA}

Afifudin, Ahmad. 2018. Pengaruh Kepemilikan Manajerial, Investment Opportunity Set, Price to Book Rasio, Political Cost dan Persistensi Laba Terhadap Konservatisme Akuntansi. Fakultas Ekonomi dan Bisnis. Jawa Tengah: Universitas Muria Kudus.

Belkaoui, Ahmed Riahi. 2011. Teori Akuntansi. Edisi 5. Buku Satu. Jakarta: Salemba Empat

Belkaoui, Ahmed Riahi. 2007. Teori Akuntansi. Edisi 5. Buku Dua. Jakarta: Salemba Empat.

Biddle, Gary C., Mary L. Ma, dan Frank M. Song. (2010). Accounting Conservatism and Bankruptcy Risk. Jurnal Akuntansi.

Brilianti, Dinny Prastiwi. (2013). Faktorfaktor yang mempengaruhi penerapan Konservatisme Akuntansi Perusahaan. Accounting Analysis Journal. Vol. 2. No. (3).

Dewi dan Suryanawa. (2014). Pengaruh Struktur Kepemilikan Manajerial , Leverage dan Financial Distress terhadap Konservatisme Akuntansi. E-Jurnal Akuntansi Universitas Udayana. Vol 7.1.

Firmasari, Dini. (2016). Pengaruh Leverage, Ukuran Perusahaan dan Financial Distress terhadap
Konservatisme Akuntansi. Fakultas Ekonomi dan Bisnis. Surabaya: Universitas Airlangga.

Fitri, Gami Amalia. (2017). Analisis Pengaruh Financial Distress, Leverage dan Kepemilikan Manajerial Perusahaan terhadap Penerapan Konservatisme dalam Akuntansi. Artikel Program Studi Akuntansi Universitas Negeri Padang.

Ghozali, Imam Prof.H.M.Com, Ph.D, CA. 2018. Aplikasi Analisis Multivariate Dengan Program SPSS 25. Edisi 9. Semarang: Badan Penerbit Universitas Diponegoro.

Hamdan, Allam Mohammed Mousa. (2011). The Impact of Company Size, Debt Contracts and Type of Sector on the Level of Accounting Conservatism: An Empirial Study from Bahrain. International Journal of Business and Magement. Vol.6, No. (7).

Hanafi, Mahmud M.Dr.M.B.A. dan Prof. Dr. Abdul Halim, M.B.S., Akt. 2016. Analisis Laporan Keuangan. Edisi 5. Yogyakarta : UPT STIM YKPN.

LaFond, Ryan. (2007). Managerial Ownership and Accounting Conservatism. Jurnal Akuntansi.

Mahardini, Nikke Yusnita.,SE.,M.Si. 2018. Analisis Laporan Keuangan. Edisi 1. Serang: Universitas Serang Raya.

Noviantari dan Ratnadi. (2015). Pengaruh Finacial Distress, Ukuran Perusahaan dan Leverage terhadap Konservatisme Akuntansi. E-Jurnal Akuntansi Universitas Udayana. Vol 11. No. (3).

Reskino dan Vemiliyarni. (2014). Pengaruh Konvergensi IFRS, Bonus Plan, Debt Covenant dan Political Cost terhadap Konservatisme Akuntansi. Jurnal 
UIN Jakarta. Vol. VII No. (3). Hal 185-195.

Rivandi dan Ariska. (2019). Pengaruh Intensitas Modal, Dividend Payout Ratio dan Financial Distress terhadap Konservatisme Akuntansi. Jurnal Benefita. Vol. 4 No. (1). Hal 104-114.

Saputra, Raja Erwin. (2016). Pengaruh Struktur Kepemilikan Manajerial, Kontrak Utang, Tingkat Kesulitan Keuangan Perusahaan, Peluang Pertumbuhan, Risiko Litigasi dan Leverage terhadap Konservatisme Akuntansi. Journal Of Management Fakultas Ekonomi. Vol.3. No.(1).

Savitri, Enni Dr.SE, MM.Ak. 2016. Konservatisme Akuntansi. Yogyakarta: Pustaka Sahila.

Susanto dan Ramadhani. (2016). Faktorfaktor yang memengaruhi Konservatisme. Jurnal Bisnis dan Ekonomi. Vol.23 No. (2). Hal 142151.

Ursula dan Adhivinna. (2018). Pengaruh Kepemilikan Manajerial, Ukuran Perusahaan, Leverage dan Growth Opportunities terhadap

Konservatisme Akuntansi. Jurnall Akuntansi Vol. 6 No. (2).

Viola dan Patricia. (2016). Pengaruh Kepemilikan Managerial, Leverage, Financial Distress dan Kepemilikan Publik terhadap Konservatisme Akuntansi. Ultima Accounting. Vol 8. No.(1).

Yanti. dkk. (2017). Pengaruh Struktur Kepemilikan Manajerial, Tingkat Utang dan Tingkat Kesulitan Keuangan Perusahaan terhadap Konservatisme Akuntansi. eJournal S1 Ak Universitas Pendidikan Ganesha. Vol.8 No. (2).

https://www.bi.go.id/id/moneter/informasikurs/transaksi-bi/Default.aspx (21 $\underline{\text { Juli 2019, pukul 19.40 WIB) }}$ https://www.idx.co.id/perusahaantercatat/laporan-keuangan-dantahunan/ (21 Juli 2019)

https://www.idnfinancials.com/id $(02$ Agustus 2019, pukul 15.00)

https://www.spssindonesia.com (24 Juni 2019, pukul 09:30 WIB 
